\title{
In Search for Aram and Israel
}

\author{
Politics, Culture, and Identity \\ Ed. by Omer Sergi, Manfred Oeming, and Izaak J. de Hulster
}

[Auf der Suche nach Aram und Israel. Politik, Kultur und Identität.]

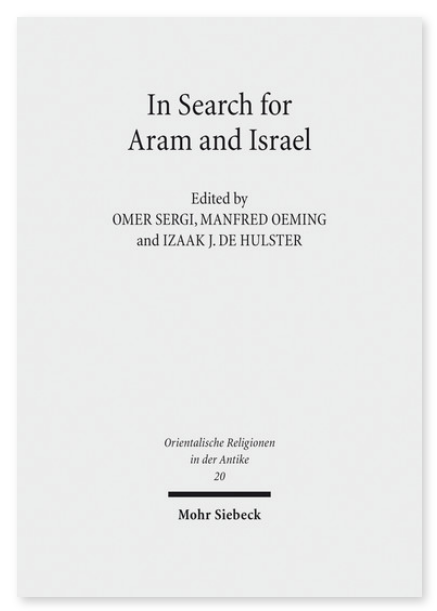

2016. XVII, 429 Seiten. ORA 20

ISBN 978-3-16-155059-1

DOI 10.1628/978-3-16-155059-1

eBook PDF 149,00€

ISBN 978-3-16-153803-2

Leinen $149,00 €$
Veröffentlicht auf Englisch.

Das Königreich Israel stand während seiner gesamten Geschichte in Verbindung zu den aramäischen Königreichen. Der ständige Wechsel von Beziehungen - von Rivalität und militärischen Konflikten zu Bündnissen und militärischer Kooperation beeinflusste die Geschichte der gesamten Levante und hinterließ Spuren sowohl in biblischen als auch außerbiblischen Quellen. Des Weiteren entstand Israel gemeinsam mit den aramäischen Stadtstaaten während des 11. bis 9. Jahrhunderts v.Chr. und das Tal des Jordan (sowie seine Ausdehnung ins Tal von Libanon) war ein Grenzgebiet, das andauernd zwischen verschiedenen Stadtstaaten der Eisenzeit wechselte. In Anbetracht dessen ist es notwendig, die Geschichte des antiken Israel nicht nur aus der »kanaanitischen« Perspektive, sondern auch im politischen und kulturellen Kontext der aramäischen Welt zu untersuchen. Dieser Band vereint Wissenschaftler aus verschiedenen Bereichen, die sich mit den Beziehungen und Interaktionen zwischen Aram und Israel während der frühen Eisenzeit (12.-8. Jahrhundert v.Chr.) befassen.

\section{Inhaltsübersicht}

Omer Sergi/lzaakJ. de Hulster: Some Historical and Methodological Considerations Regarding the Question of Political, Social and Cultural Interaction between Aram and Israel in the Early Iron Age

\section{Aram and Israel: Political Relations, Political Borders}

Israel Finkelstein: Israel and Aram: Reflections on their Border - Erhard Blum: The Relations between Aram and Israel in the 9th and 8th Centuries BCE: The Textual Evidence - Assaf Kleiman: The Damascene Subjugation of the Southern Levant as a Gradual Process (ca. 842-800 BCE)

\section{In Search of 'Aramaean' Material Culture}

Aren M. Maeir: The Aramaean Involvement in the Southern Levant: Case Studies for Identifying the Archaeological Evidence Amihai Mazar: Culture, Identity and Politics Relating to Tel Rehov in the 10th-9th Centuries BCE (with an Excursus on the Identification of Tel Reḥov) - Jutta Häser/Katja Soennecken/Dieter Vieweger: Tall Zirā'a in north-west Jordan between Aram and Israel - Nava Panitz-Cohen/Robert A. Mullins: Aram-Maacah? Aramaeans and Israelites on the Border: Excavations at Tell Abil el-Qameh (Abel-beth-maacah) in Northern Israel - Yifat Thareani: Enemy at the Gates? The Archaeological Visibility of the Aramaeans at Dan - Benjamin Sass: Aram and Israel during the 10th-9th centuries BCE, or Iron Age IIA: The Alphabet - Izaak J. de Hulster: Material Aramaeisms? Sphragistic Reflections on the Aram-Israel Border Zone through a Case Study on Hazor

III. Aram and Israel: the Question of Identity

Guy Bunnens: Confrontation, Emulation and Ethno-genesis of the Aramaeans in Iron Age Syria - Stefania Mazzoni: Identity and Multiculturality in the Northern Levant of the 9th-7th century BCE: With a Case Study on Tell Afis - Herbert Niehr: The Power of Language: Language Situation and Language Policy in Sam'al - Omer Sergi: The Gilead between Aram and Israel: Political Borders, Cultural Interaction, and the Question of Jacob and Israelite Identity - Angelika Berlejung: Family Ties: Constructed Memories about Aram and the Aramaeans in the Old Testament - Nili Wazana: Ahaz and the Altar from Damascus (2 Kings 16:10-16): Literary, Theological, and Historical-Political Considerations - Manfred Oeming: »And the King of Aram was at war with Israel«: History and Theology in the Elisha Cycle 2 Kings 2-13

Omer Sergi Born 1977; 2013 PhD; since 2014 Lecturer at the Department of Archaeology and Ancient Near Eastern Cultures, Tel Aviv University.

https://orcid.org/0000-0002-1613-691X

Manfred Oeming Geboren 1955; 1984 Promotion und 1989 Habilitation in Bonn; seit 1996 Professor für alttestamentliche Theologie an der Universität Heidelberg.

Izaak J. de Hulster Born 1979; 2008 PhD (Utrecht); since 2014 University Researcher at the Faculty of Theology, University of Helsinki; 2017 Habilitation (Göttingen).

https://orcid.org/0000-0003-0706-4480

Jetzt bestellen:

https://mohrsiebeck.com/buch/in-search-for-aram-and-israel-9783161550591?no_cache=1

order@mohrsiebeck.com

Telefon: +49 (0)7071-923-17 
Telefax: +49 (0)7071-51104

Mohr Siebeck GmbH \& Co. KG

Postfach 2040

D-72010 Tübingen

info@mohrsiebeck.com

Mohr Siebeck

www.mohrsiebeck.com 